\title{
Long-Term Efficacy and Tolerability of Lanthanum Carbonate: Results from a 3-Year Study
}

\author{
Alastair J. Hutchison ${ }^{a}$ Bart Maes $^{b}$ Johan Vanwalleghem ${ }^{c}$ Gernot Asmus $^{d}$ \\ Elfatih Mohamed ${ }^{a}$ Roland Schmieder ${ }^{e}$ Wolfgang Backs $^{f}$ Rene Jamar $^{g}$ \\ Andre Vosskühler ${ }^{h}$ \\ ${ }^{a}$ Manchester Royal Infirmary, Manchester, UK; ${ }^{\mathrm{b}}$ Universitair Ziekenhuis Gasthuisberg, Leuven, Belgium; \\ ${ }^{c}$ Virga Jesse Ziekenhuis, Hasselt, Belgium; ${ }^{d} \mathrm{KfH}-$ Dialysezentrum, Berlin, Germany; ${ }^{\mathrm{e}}$ Friedrich-Alexander- \\ Universität Erlangen-Nürnberg, Erlangen, Germany; ${ }^{f}$ Dialysezentrum Barmbek, Hamburg, Germany; \\ ${ }^{\mathrm{g}}$ Imelda Ziekenhuis, Bonheiden, Belgium; ${ }^{\mathrm{h}} \mathrm{KfH}$-Dialysezentrum, Bottrop, Germany
}

\section{Key Words}

Chronic renal failure $\cdot$ Hyperphosphatemia

Lanthanum carbonate

\begin{abstract}
Background: Control of serum phosphate over the long term is essential in patients with end-stage renal disease. Six-month and 2-year extensions to a 6-month study evaluated the long-term safety, tolerability and efficacy of the new phosphate binder lanthanum carbonate. Methods: Patients who participated in a 6-month, randomized trial comparing lanthanum carbonate with calcium carbonate were eligible for a 24-week, open-label extension. Lanthanum carbonate-treated patients continued taking their established maintenance dose ('continued-lanthanum group') and calcium carbonate-treated patients switched to lanthanum carbonate, $375-3,000$ $\mathrm{mg} /$ day ('switch group'). Patients could also enter a further 2-year extension. Efficacy parameters, including serum phosphate, were monitored. Results: Mean serum phosphate was $\sim 1.80 \mathrm{mmol} / \mathrm{l}$ throughout the trial. The percentage of patients with controlled serum phosphate $(\leq 1.80 \mathrm{mmol} / \mathrm{l})$ after the 6 -month extension was 63.3 and
\end{abstract}

$58.4 \%$ in the continued-lanthanum and switch groups, respectively; after the 2 -year extension, $54.4 \%$ of patients had controlled serum phosphate. After discontinuation of calcium carbonate and initiation of lanthanum carbonate, the hypercalcemia incidence was $2.7 \%$, compared with $20.2 \%$ during the double-blind phase. Calcium $\times$ phosphate product was maintained at an acceptable level. Lanthanum carbonate was well tolerated; adverse events were mild/moderate and mainly gastrointestinal. Conclusions: Lanthanum carbonate maintains effectiveness with continued tolerability for up to 3 years.

Copyright (C) 2006 S. Karger AG, Basel

\section{Introduction}

Elevated serum phosphate is a common complication of end-stage renal disease (ESRD), affecting up to $70 \%$ of dialysis patients, despite dietary restrictions and the use of phosphate-binding agents [1]. The clinical consequences of hyperphosphatemia are well documented and include cardiovascular and other metastatic calcifications, secondary hyperparathyroidism and renal bone disease [2-4]. High serum phosphate in patients with ESRD in-

\section{KARGER \\ Fax +4161306 1234 E-Mail karger@karger.ch} www.karger.com (c) 2006 S. Karger AG, Basel $1660-2110 / 06 / 1022-0061 \$ 23.50 / 0$

Accessible online at: www.karger.com/nec
Dr. Alastair Hutchison

Manchester Royal Infirmary, Oxford Road

Manchester M13 9WL (UK)

Tel. +44161276 1234, Fax +441612768022

E-Mail alastair.hutchison@cmmc.nhs.uk 
evitably leads to deposition of the excess as calcium phosphate in soft tissues. In addition, phosphate has more recently been implicated as an instigator of an active process of metastatic calcification, whereby vascular smooth muscle cells are converted to osteoblast-like calcifying cells [5]. Clearly, phosphate control is an important issue in the treatment of patients with ESRD.

Calcification of the vasculature occurs in more than $50 \%$ of dialysis patients $[6,7]$ and may contribute to the high cardiovascular mortality rate observed in this patient population [8]. Indeed, calcification of the cardiac valves is known to be a powerful predictor of mortality and cardiovascular death in patients undergoing long-term dialysis [9]. The incidence and severity of calcification have been shown to increase with the duration of ESRD [10]. As patients with ESRD often remain on dialysis for many years, phosphate binders that both maintain control of serum phosphate over the long term, and are well tolerated, are an essential part of efforts to tackle the burden of cardiovascular disease in patients with ESRD.

Traditionally, aluminium- and calcium-based phosphate binders have been the mainstay of treatment for hyperphosphatemia. Both of these types of phosphate binder have demonstrated efficacy in the short term; however, neither are recommended for long-term use. Aluminium, although highly potent, is recommended as a short-term 'rescue' therapy only, as numerous safety concerns restrict its use in the long term [11]. The long-term use of calcium-based agents has been associated with calcification and oversuppression of parathyroid hormone (PTH) [12], although their use in nonhypercalcemic patients at doses up to $1,500 \mathrm{mg} /$ day elemental calcium is recommended in guidelines issued by the National Kidney Foundation in the USA [13].

It was hoped that sevelamer hydrochloride, a nonaluminium-, noncalcium-based synthetic polymer, would represent a suitable alternative agent to the traditional treatment options. Sevelamer has shown similar efficacy to that of calcium-based agents in a number of randomized short- and longer-term clinical trials $[14,15]$, although a more recent short-term study has shown calcium acetate to be more effective [16]. In addition, the potency of sevelamer does not match that of aluminium [17].

Lanthanum carbonate $\left(\right.$ FOSRENOL $^{\circledR}$, Shire Pharmaceuticals) is a nonaluminium, noncalcium phosphate binder that binds dietary phosphate at a clinically relevant $\mathrm{pH}$ range. It has demonstrated potency similar to that of aluminium in the pre-clinical setting [17], but lacks aluminium-like toxicity in bone [18-20]. Lanthanum is poorly absorbed from the intestinal tract, with peak steady- state plasma concentrations in dialysis patients of approximately $1 \mathrm{ng} / \mathrm{ml}$. As the absorbed fraction is not cleared by the kidneys but by the enterohepatic biliary route, plasma exposure and pharmacokinetics of lanthanum are similar in healthy individuals and patients with ESRD [21]. Bone and liver have been shown to be sites of tissue deposition of lanthanum; however, absolute concentrations are low because of the poor absorption of lanthanum and have not been associated with toxicity [21,22]. In animals, the central nervous system (CNS) was not a site of tissue deposition for lanthanum, and long-term studies demonstrated that lanthanum carbonate has no CNS toxicity [21, 22]. Studies suggesting more widespread tissue deposition of lanthanum in animals involved administration of the drug in a powdered diet [23], and consequently may have been complicated by inhalation of drug particles and sample contamination [24].

In a 6-month, randomized, open-label, parallel-group trial comparing lanthanum carbonate with calcium carbonate, lanthanum carbonate was shown to be an effective treatment for hyperphosphatemia with good safety and tolerability [25]. Lanthanum carbonate (750-3,000 $\mathrm{mg}$ /day lanthanum) had similar efficacy to calcium carbonate (1,500-9,000 mg/day calcium), although calcium carbonate was associated with a much higher occurrence of hypercalcemia. Given the concerns that many authors have expressed over long-term treatment with traditional phosphate binders and possible effects of metal accumulation, a series of open-label extensions was designed to investigate longer-term safety and tolerability in patients receiving lanthanum carbonate for a maximum period of 3 years.

\section{Methods}

\section{Study Design}

This open-label extension to the previous 6-month comparatorcontrolled trial consisted of two parts. The first part was a 6-month extension carried out at 67 centers in the UK, Germany, Belgium and The Netherlands. The second was a 2-year extension carried out at 34 of these centers in the UK, Germany and Belgium, and was initiated at the request of investigators and patients who participated in the previous phases of the study. The design of the original comparator-controlled trial has been reported elsewhere [25] and is briefly summarized here.

\section{Open-Label, Comparator-Controlled Phase}

After a phosphate-binder washout period of 1-3 weeks, hemodialysis patients with uncontrolled phosphate levels (defined as $>1.80 \mathrm{mmol} / 1[5.6 \mathrm{mg} / \mathrm{dl}]$ ) were randomized in a $2: 1$ ratio to receive either oral lanthanum carbonate $(375-3,000 \mathrm{mg}$ /day of elemental lanthanum) or oral calcium carbonate $(1,500-9,000 \mathrm{mg} / \mathrm{day}$ of 
elemental calcium) for 5 weeks during a dose-titration period. Both treatments were given as divided doses with meals. Patients who had shown a response to phosphate binders at the end of the titration period continued to the 20 -week comparative efficacy phase.

\section{Six-Month Open-Label Extension}

Patients who entered the initial phase were eligible to participate in a 24-week open-label extension in which all patients received lanthanum carbonate. Patients were not required to complete the comparator phase, although patients receiving lanthanum carbonate who withdrew from the comparator-controlled trial because of adverse events were not eligible for the extension study.

\section{Two-Year Open-Label Extension}

Patients were eligible to enter the optional 2-year extension study if they had participated in the previous phases of the trial and had received at least one dose of lanthanum carbonate (it was not necessary to have completed either of the previous phases). After approval from the Institutional Review Board, patients were able to begin the 2-year extension either immediately after finishing the 6-month open-label phase or after a gap in treatment (after withdrawal from either previous phase). Additionally, inclusion and exclusion criteria that had applied in the original screening of the first phase of the trial were still valid in this phase.

\section{Dosage}

Patients who received lanthanum carbonate in the open-label comparator phase continued to receive lanthanum at the optimal dose established (375-3,000 mg/day of lanthanum, taken in divided doses with meals). Patients who received calcium carbonate during the comparator-controlled phase were switched at the start of the 6-month extension and titrated to optimum lanthanum carbonate treatment over a 5-week period. In these patients, serum phosphate levels were monitored weekly until the optimum dose of lanthanum carbonate was reached to maintain levels at or below $1.80 \mathrm{mmol} / \mathrm{l}$. Patients who began the 2-year extension after an interval of more than 2 months from the end of the previous phase also had their dose of lanthanum titrated. During both extension phases, the dose of lanthanum could be titrated as necessary within the available dose range of $375-3,000 \mathrm{mg} /$ day.

\section{Assessments}

The main aim of the extension studies was to assess the longterm safety and tolerability of lanthanum carbonate in patients on hemodialysis. Adverse events, hematology and biochemical parameters were monitored at every study visit (every month during the 6-month extension and every 2 months thereafter). Plasma lanthanum levels were determined at the beginning of the extension (6 months) and at 9, 12, 18, 24, 30 and 36 months.

Serum phosphate was monitored by taking blood samples at every study visit. Control of serum phosphate was defined in the 6 -month extension as a level of $\leq 1.80 \mathrm{mmol} / 1$. There was no predefined target level in the 2-year extension. Serum calcium, PTH and vitamin $\mathrm{D}$ were also monitored at 6, 9, 12, 18, 24, 30 and 36 months, and the calcium $\times$ phosphate product $(\mathrm{Ca} \times \mathrm{P})$ was calculated. The study was conducted according to International Conference on Harmonization (ICH) Guidelines for Good Clinical Practice. Written, informed consent was obtained from all patients at the start of the original comparator-controlled phase and again before entering the 2-year extension.

Long-Term Efficacy and Tolerability of Lanthanum Carbonate

\section{Statistical Analysis}

In the 6-month extension, the intent-to-treat (ITT) population was the primary analysis. This population was defined as all those patients who entered the extension study, who had received at least one dose of treatment and who had efficacy measurements during the comparator-controlled phase. Nominal or binary data (e.g. proportion of patients with controlled phosphate) were analyzed using the $\chi^{2}$ or Fisher's exact test. Ordered categorical data, such as the frequency of uncontrolled phosphate reports, were analyzed using the Cochran Mantel Haenszel test with integer scores. Continuous, normally distributed data (e.g. serum phosphate and calcium levels) were analyzed by analysis of variance (ANOVA) or analysis of covariance (ANCOVA).

In the 2-year extension, the safety population, defined as all patients receiving at least one dose of study medication, was used for all safety and efficacy assessments. In addition, a subgroup of patients, termed the 'long-term-exposure group', was identified. These patients had completed all three phases and had consequently received lanthanum carbonate for at least 152 weeks, having demonstrated continued response and tolerability to lanthanum carbonate throughout the trial. Key parameters were analyzed in this group as well as in the safety population.

Adverse events were coded using the World Health Organization Adverse Reaction Terminology (WHO-ART) 98.3 dictionary, according to preferred term and body system. Efficacy data analyses and reporting were all conducted using SAS software (version 6.12).

\section{Results}

\section{Patient Disposition}

In total, 518 patients from the comparator-controlled trial entered the 6-month extension (185 patients switched from calcium carbonate to lanthanum carbonate and 333 continued with lanthanum carbonate) (fig. 1). Of these, 375 patients completed this phase: $262(79 \%)$ in the group that continued to receive lanthanum (49 weeks of lanthanum carbonate treatment) and $113(61 \%)$ in the switch group (at least 24 weeks of lanthanum carbonate treatment). All patients entering the study were included in the safety analysis. Efficacy data for 5 patients were not included in the final data analysis because of the unreliability of the data generated at one center. The ITT analysis population therefore comprised 513 patients: 332 in the continued-lanthanum group and 181 in the switch group. Demographic data for this population are shown in table 1.

After completion of the 6-month extension, 161 patients entered the optional 2-year extension phase and received at least one dose of lanthanum carbonate. Twenty-one patients entered the extension straight from the previous 6-month extension to the open-label phase, with no gap in treatment; 26 had a gap of less than 2 months 
and 114 had a gap of more than 2 months. Eighty-three patients completed the full 24 months and 78 discontinued. The long-term-exposure group comprised 46 patients who had received a cumulative total of 152 weeks or more of lanthanum carbonate treatment throughout the trial (fig. 1). Demographic parameters and other characteristics of the safety and the long-term-exposure populations, which were taken from the original screening data in the first phase of the trial, are summarized in table 1.

\section{Six-Month Extension}

In the group that continued to receive lanthanum carbonate treatment in the 6-month extension, the mean serum phosphate level after 24 weeks was $1.76 \pm 0.56$ $\mathrm{mmol} / \mathrm{l}(5.5 \pm 1.7 \mathrm{mg} / \mathrm{dl}$ ) (fig. 2). The proportion of patients with controlled serum phosphate levels in the continued-lanthanum group at the end of the 6-month extension was $63.3 \%$. For the switch group, the mean phosphate level at the end of the 6-month extension was 1.83 $\pm 0.52 \mathrm{mmol} / 1(5.7 \pm 1.6 \mathrm{mg} / \mathrm{dl})$ (fig. 2). During lanthanum carbonate treatment, the proportion of patients with controlled levels increased from $46.1 \%$ at 4 weeks to $58.4 \%$ after 24 weeks.

Fig. 1. Study design and patient disposition. $\mathrm{LC}=$ Lanthanum carbonate; $\mathrm{CC}=$ calcium carbonate.

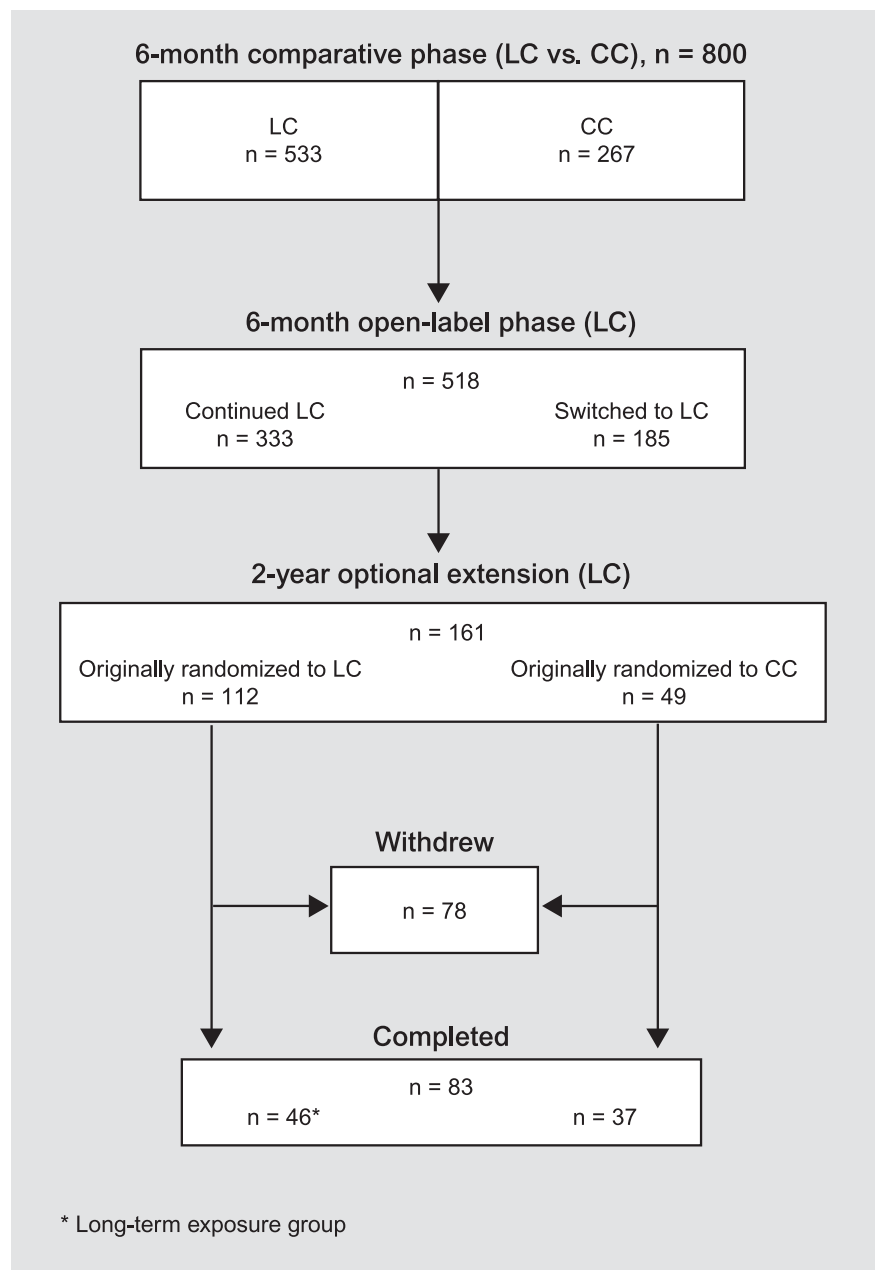

Table 1. Baseline (week 0) characteristics for patients entering the extension studies

\begin{tabular}{|c|c|c|c|c|}
\hline \multirow[t]{2}{*}{ Characteristic } & \multicolumn{2}{|c|}{ 6-month extension phase } & \multicolumn{2}{|c|}{ 2-year extension phase } \\
\hline & $\begin{array}{l}\text { continued lanthanum } \\
\text { group }(\mathrm{n}=332)\end{array}$ & $\begin{array}{l}\text { switch group } \\
(\mathrm{n}=181)\end{array}$ & $\begin{array}{l}\text { total population } \\
(\mathrm{n}=161)\end{array}$ & $\begin{array}{l}\text { long-term exposure } \\
\text { group }(n=46)\end{array}$ \\
\hline Age, mean $\pm \mathrm{SD}$, years & $57.0 \pm 14.6$ & $58.6 \pm 13.6$ & $56.5 \pm 14.5$ & $56.3 \pm 15.5$ \\
\hline \multicolumn{5}{|l|}{ Gender } \\
\hline Male, $\%$ & 67.2 & 65.2 & 68.3 & 63.0 \\
\hline Female, $\%$ & 32.8 & 34.8 & 31.7 & 37.0 \\
\hline \multicolumn{5}{|l|}{ Ethnic origin } \\
\hline Caucasian, \% & 97.0 & 96.7 & 98.1 & 100.0 \\
\hline Afro-Caribbean, $\%$ & 2.1 & 1.1 & 0.6 & 0 \\
\hline Other, $\%$ & 0.9 & 2.2 & 1.2 & 0 \\
\hline \multicolumn{5}{|l|}{ Primary diagnosis } \\
\hline Diabetes, $\%$ & 14.2 & 14.4 & 21.7 & 28.3 \\
\hline Hypertension, $\%$ & 10.5 & 11.0 & 9.9 & 13.0 \\
\hline Glomerulonephritis, $\%$ & 28.9 & 28.7 & 21.7 & 17.4 \\
\hline Cystic kidney disease, $\%$ & 11.4 & 15.5 & 11.2 & 8.7 \\
\hline Urological disease, $\%$ & 6.9 & 6.1 & 8.1 & 6.5 \\
\hline Other, $\%$ & 28.1 & 24.3 & 27.3 & 26.0 \\
\hline Time on dialysis, mean \pm SD (months) & $41.8 \pm 36.9$ & $42.7 \pm 45.0$ & $45.1 \pm 39.4$ & $35.6 \pm 33.6$ \\
\hline
\end{tabular}


Fig. 2. Mean serum phosphate levels $( \pm$ 95\% CIs) during the original 6-month comparator study [23] and the 6-month extension. To convert to $\mathrm{mg} / \mathrm{dl}$, multiply by 3.1 .
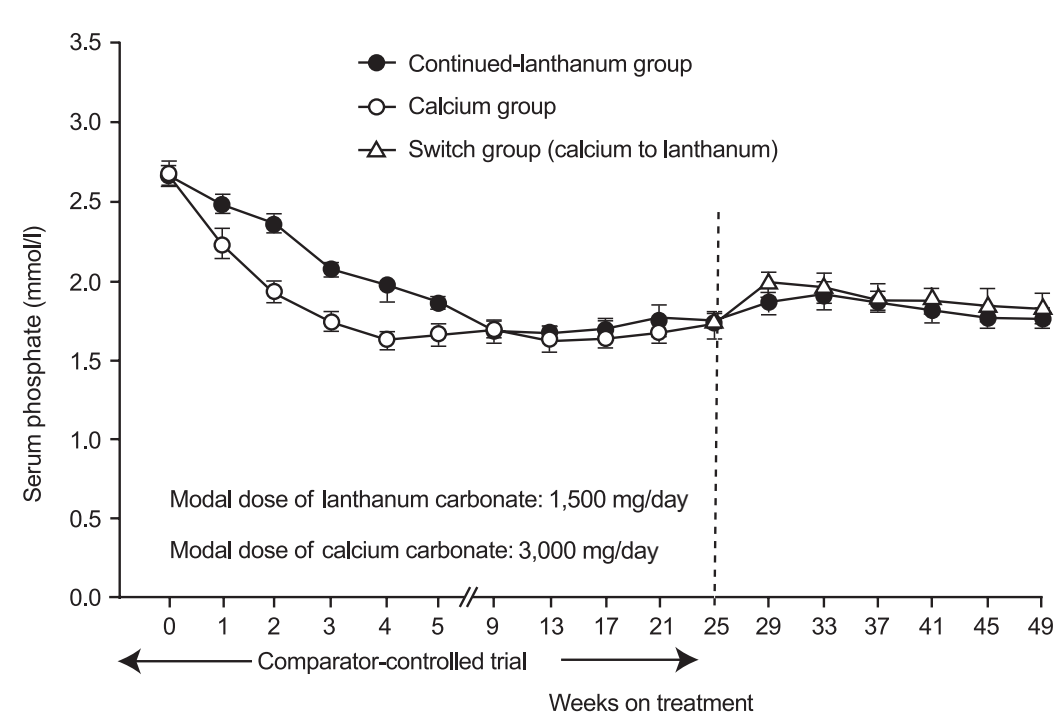

$\psi$ values

\begin{tabular}{|l|lllllllllllllllll|}
\hline & \multicolumn{11}{|c|}{ Week } \\
\hline & 0 & 1 & 2 & 3 & 4 & 5 & 9 & 13 & 17 & 21 & 25 & 29 & 33 & 37 & 41 & 45 & 49 \\
\hline Lanthanum & 504 & 499 & 493 & 479 & 466 & 453 & 277 & 255 & 242 & 228 & 222 & 330 & 313 & 292 & 286 & 266 & 259 \\
Calcium & 254 & 253 & 238 & 231 & 212 & 209 & 152 & 138 & 131 & 117 & 122 & 165 & 139 & 133 & 127 & 114 & 113 \\
\hline
\end{tabular}

Table 2. Mean serum calcium levels in the 6-month extension phase in patients who switched from calcium carbonate to lanthanum carbonate treatment

\begin{tabular}{ll}
\hline & $\begin{array}{l}\text { Serum calcium } \\
\mathrm{mmol} / \mathrm{I}^{*}\end{array}$ \\
\hline $\begin{array}{c}\text { At end of washout of previous } \\
\text { comparator-controlled phase }\end{array}$ & $\begin{array}{l}2.35 \\
(\text { range } 1.20-3.05)\end{array}$ \\
$\begin{array}{c}\text { At end of previous comparator-controlled } \\
\text { phase }\end{array}$ & $\begin{array}{l}2.45 \\
\text { (range 1.85-3.15) }\end{array}$ \\
$\begin{array}{c}\text { After 12 weeks of lanthanum carbonate } \\
\text { treatment }\end{array}$ & $\begin{array}{l}2.33 \\
(\text { range } 0.55-2.95)\end{array}$ \\
$\begin{array}{c}\text { After 24 weeks of lanthanum carbonate } \\
\text { treatment }\end{array}$ & $\begin{array}{l}2.35 \\
(\text { range } 0.72-3.00)\end{array}$ \\
\hline
\end{tabular}

* To convert to mg/dl, multiply by 4 .

In the continued-lanthanum group, $\mathrm{Ca} \times \mathrm{P}$ levels remained largely unchanged throughout the 6-month extension study. Mean serum levels were $4.20 \pm 1.37$ $\mathrm{mmol}^{2} / \mathrm{l}^{2}\left(52.1 \pm 17.0 \mathrm{mg}^{2} / \mathrm{dl}^{2}\right)$ after 24 weeks. In the switch group, $\mathrm{Ca} \times \mathrm{P}$ levels decreased from $4.52 \pm 1.30$ $\mathrm{mmol}^{2} / \mathrm{l}^{2}\left(56.0 \pm 16.1 \mathrm{mg}^{2} / \mathrm{dl}^{2}\right)$ at 4 weeks to $4.29 \pm 1.27$ $\mathrm{mmol}^{2} / \mathrm{l}^{2}\left(53.2 \pm 15.7 \mathrm{mg}^{2} / \mathrm{dl}^{2}\right)$ after 24 weeks of lantha- num carbonate treatment. Mean serum calcium levels in patients who had received lanthanum carbonate in the previous comparative phase remained unchanged or decreased marginally. Only 1 patient $(0.3 \%)$ in the continued-lanthanum group experienced hypercalcemia (i.e. any serum calcium level above the upper limit of normal, which is $2.65 \mathrm{mmol} / 1$ [10.6 mg/dl]) during the 6-month extension. In patients who had received calcium carbonate, mean serum calcium levels declined to the baseline value of the previous phase after 24 weeks of lanthanum treatment (table 2). Hypercalcemia was experienced by $2.7 \%$ of these patients during the 6-month extension, compared with $20.2 \%$ in the comparator-controlled phase [25]. The median PTH level at the end of the 6-month extension was $235 \mathrm{ng} / \mathrm{l}(0-2,300 \mathrm{ng} / \mathrm{l})$ in patients who continued to receive lanthanum carbonate and 196.5 $\mathrm{ng} / \mathrm{l}(7-1,821 \mathrm{ng} / \mathrm{l})$ in those who switched from calcium carbonate.

The most common adverse events during the 6-month extension were gastrointestinal in nature and were rated as mild in severity. Adverse events occurring in more than $5 \%$ of patients in the 6-month extension are shown in table 3. Drug-related adverse events were reported by $17.1 \%$ of patients in the continued-lanthanum group and 
$31.4 \%$ of patients in the switch group during the initial 6-month extension. Serious adverse events occurred in 198 patients $(38.2 \%)$ during the 6-month extension: $37.5 \%$ of patients in the continued-lanthanum group and $39.5 \%$ in the switch group. Generally, the type and incidence of serious adverse events were similar to the events reported during the comparator-controlled phase [25] and typical of a population with ESRD (e.g. dialysis complications, renal transplants, cardiovascular events). No serious adverse event or death during the 6-month extension was considered by the investigators to be related to lanthanum carbonate treatment. The incidence of death (3.6\% [ 12 patients] in the continued-lanthanum group and $4.9 \%$ [9 patients] in the switch group) was no greater than that expected in a population of patients with chronic kidney disease [26].

\section{Two-Year Extension}

Of the 161 patients entering the optional 2-year extension, 116 were re-titrated between weeks 49 and 58 in order to re-establish optimal control of serum phosphate. At week 58, all patients had been re-titrated, and the various doses were administered at a frequency of: $11 \%$ (750 mg), 27\% (1,500 mg), 30\% (2,250 mg) and 32\% $(3,000 \mathrm{mg})$. There was minimal change in dose throughout the extension phases of the study.

At the start of the 2-year extension, mean serum phosphate level was $2.03 \mathrm{mmol} / \mathrm{l}(6.29 \mathrm{mg} / \mathrm{dl})$. After 2 months, and re-titration of patients, mean serum phosphate had decreased to $1.83 \mathrm{mmol} / \mathrm{l}(5.67 \mathrm{mg} / \mathrm{dl}$ ) (fig. 3). Patients in the long-term-exposure group - those completing all phases of the trial - had a mean serum phosphate level that was consistently lower than that of the safety population (fig. 3). A greater proportion of patients from this group had serum phosphate levels at each time point that met the criteria defined for control in the earlier phases of the trial. By the end of the study, serum phosphate levels were $\leq 1.80 \mathrm{mmol} / \mathrm{l}(\leq 5.6 \mathrm{mg} / \mathrm{dl})$ in $69 \%$ of the longterm-exposure group and in $54 \%$ of the overall safety population.

Throughout the 2-year extension, the mean $\mathrm{Ca} \times \mathrm{P}$ level showed a substantial decrease, from $5.07 \mathrm{mmol}^{2} / \mathrm{l}^{2}$ $\left(62.9 \mathrm{mg}^{2} / \mathrm{dl}^{2}\right)$ at week 49 to $3.92 \mathrm{mmol}^{2} / \mathrm{l}^{2}\left(48.6 \mathrm{mg}^{2} / \mathrm{dl}^{2}\right)$ at week 75 . For the remainder of the study, $\mathrm{Ca} \times \mathrm{P}$ levels remained relatively constant (table 4).

Mean serum calcium levels remained within values considered to be representative of a normal range (2.05$2.65 \mathrm{mmol} / 1[8.2-10.6 \mathrm{mg} / \mathrm{dl}]$ ) during the 2-year extension, although the level was marginally higher than this at the beginning of this phase (week 49). During the 2-year
Table 3. Adverse events (AEs) during the 6-month extension study in the continued-lanthanum group $(\mathrm{n}=333)$ and the switch group $(\mathrm{n}=185)$

\begin{tabular}{|c|c|c|}
\hline & $\begin{array}{l}\text { Continued } \\
\text { lanthanum } \\
\text { group, n }(\%)\end{array}$ & $\begin{array}{l}\text { Switch } \\
\text { group, n (\%) }\end{array}$ \\
\hline $\begin{array}{l}\text { Number of patients reporting at } \\
\text { least one } \mathrm{AE}\end{array}$ & $297(89.2)$ & 169 (91.4) \\
\hline Total number of AEs & 1,337 & 824 \\
\hline $\begin{array}{l}\text { Number of patients with at least } \\
\text { one drug-related } \mathrm{AE}\end{array}$ & $57(17.1)$ & $58(31.4)$ \\
\hline $\begin{array}{l}\text { Number of patients withdrawn } \\
\text { owing to AEs }\end{array}$ & $75(22.5)$ & $61(33.0)$ \\
\hline Number of patients with a serious & & \\
\hline $\mathrm{AE}$ & $125(37.5)$ & $73(39.5)$ \\
\hline Number of patients who died & $12(3.6)$ & $9(4.9)$ \\
\hline AEs occurring in $\geq 5 \%$ of patients & & \\
\hline Hypotension & $37(11.1)$ & $21(11.4)$ \\
\hline Headache & $23(6.9)$ & $14(7.6)$ \\
\hline Dialysis graft occlusion & $22(6.6)$ & $16(8.6)$ \\
\hline Abdominal pain & $15(4.5)$ & $10(5.4)$ \\
\hline Diarrhea & $39(11.7)$ & $25(13.5)$ \\
\hline Nausea & $50(15)$ & $30(16.2)$ \\
\hline Vomiting & $45(13.5)$ & $31(16.8)$ \\
\hline Hypocalcemia & $4(1.2)$ & $10(5.4)$ \\
\hline Cramps & $36(10.8)$ & $19(10.3)$ \\
\hline Bronchitis & $29(8.7)$ & $9(4.9)$ \\
\hline Rhinitis & $28(8.4)$ & $17(9.2)$ \\
\hline
\end{tabular}

period, $63 \%$ of patients had no hypercalcemic episodes, and $17 \%$ of patients had just a single hypercalcemic episode (fig. 4). The proportion of patients experiencing hypercalcemic events tended to decrease with the length of treatment. This was partly due to the fact that patients who did not tolerate the drug were withdrawn from the study, resulting in a biased patient subset in the longterm-exposure group.

Throughout the 2-year extension, PTH levels remained broadly unchanged in a high proportion of patients (43\%). Among the remaining patients, PTH levels showed a slight tendency to rise, with a greater proportion of patients experiencing an increase in PTH levels, compared with those who experienced a decrease (33 vs. $24 \%$ ). In the long-term-exposure group, a greater proportion of patients moved from low or high PTH levels toward levels deemed in this study to represent normal bone turnover (101-300 ng/ml; 35\% in the long-term-exposure group vs. $23 \%$ in the safety population). During the 2 years of this extension, 115 patients $(71 \%)$ received vitamin D therapy. 
Fig. 3. Mean serum phosphate levels during the 2-year extension. To convert to $\mathrm{mg} / \mathrm{dl}$, multiply by 3.1 .

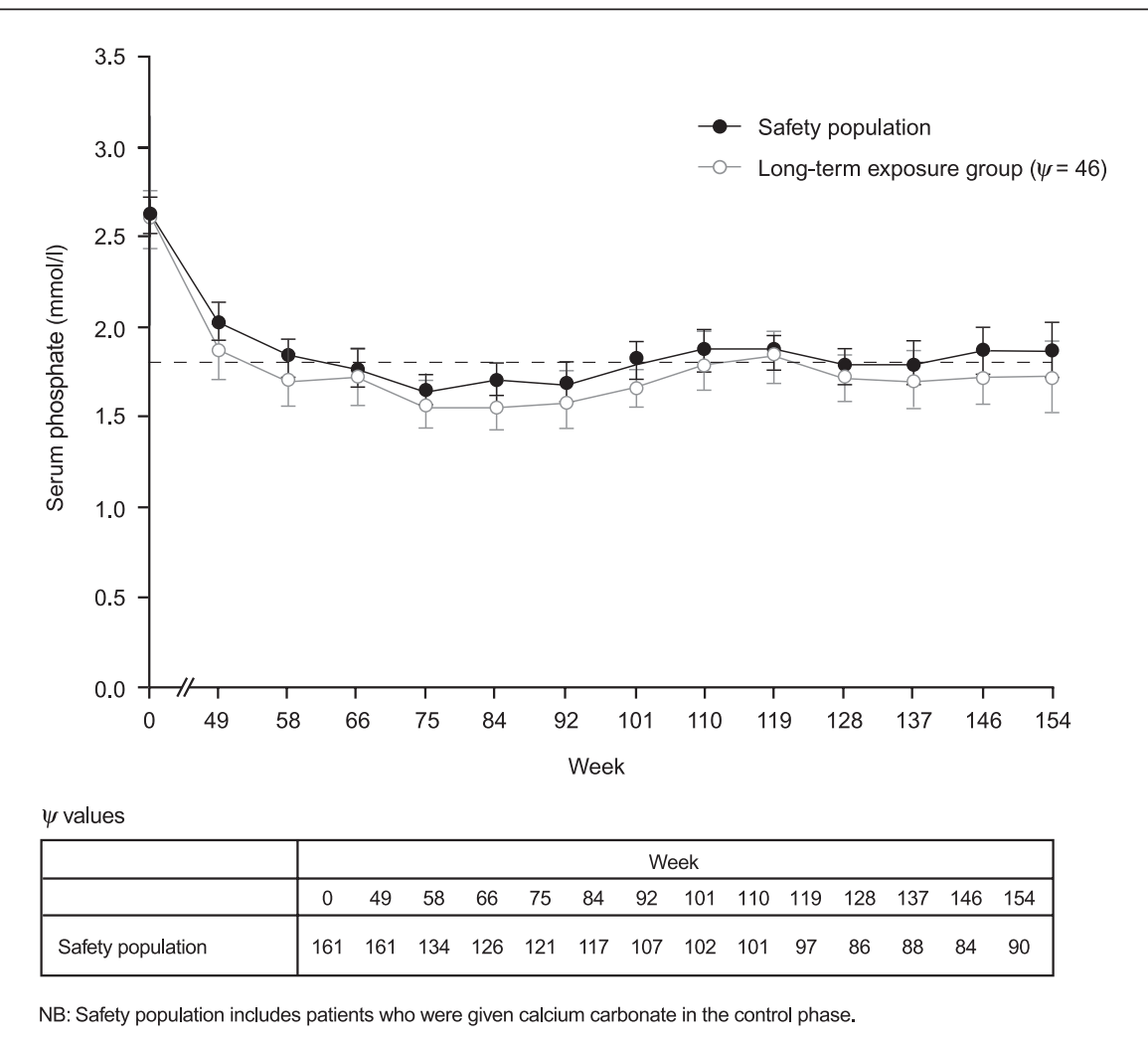

Table 4. Mean $\mathrm{Ca} \times \mathrm{P}$ levels throughout the 2-year extension

\begin{tabular}{cll}
\hline Weeks on treatment & $\mathrm{n}$ & $\begin{array}{l}\mathrm{Ca} \times \mathrm{P}, \mathrm{mmol}^{2} / \mathrm{1}^{2 \mathrm{a}} \\
(\mathrm{mean} \pm \mathrm{SD})\end{array}$ \\
\hline 0 & 159 & $5.91 \pm 1.69$ \\
$49^{\mathrm{b}}$ & 161 & $5.07 \pm 1.73$ \\
75 & 121 & $3.92 \pm 1.21$ \\
101 & 102 & $4.24 \pm 1.28$ \\
128 & 85 & $4.33 \pm 1.17$ \\
154 & 90 & $4.26 \pm 1.74$ \\
\hline
\end{tabular}

a To convert to $\mathrm{mg}^{2} / \mathrm{dl}^{2}$, multiply by 12.4 .

${ }^{\mathrm{b}}$ The precise start date of the 2-year extension varied according to when patients started lanthanum carbonate treatment.

The overall incidence of adverse events was higher in the 2-year extension than in previous phases, reflecting the longer duration of the study. A total of 1,810 adverse events were reported by $92 \%$ of patients during this phase. Table 5 lists the most frequently reported adverse events ( $>1$ patient). In total, only 50 adverse events $(2.8 \%)$ were considered likely to be related to treatment. Of all adverse events reported in the 2-year extension, only 44 (2.4\%) led to withdrawal from the study. In the long-term-exposure group, the incidence of adverse events remained relatively constant over the full 3 years, and no new event, or any increase of frequency or severity, was observed during treatment.

Serious adverse events in the 2-year extension were generally similar to those occurring in the earlier phases of the trial: dialysis complications accounted for 19.4\% of all serious adverse events and renal transplantation for a further $7.4 \%$. Serious adverse events occurred with a slightly higher incidence in this phase $(64.0 \%$ of patients, compared with $21.4 \%$ of lanthanum carbonate-treated patients in the 6-month comparative phase and $38.2 \%$ of patients in the 6-month open-label extension phase); this was expected as this extension was four times longer in duration than the previous phases of the trial. In total, 14 deaths $(8.7 \%)$ occurred during the 2-year study duration. No deaths were considered likely to be related to treatment with lanthanum carbonate. Only one serious adverse event (aggravated hyperparathyroidism) was considered by the study investigator likely to be related to treatment as a relationship to lanthanum carbonate could 
Fig. 4. Number of hypercalcemic episodes (serum calcium $>2.65 \mathrm{mmol} / 1$ [10.6 mg/dl]) experienced by patients in the safety population $(n=161)$ during the 2-year extension.

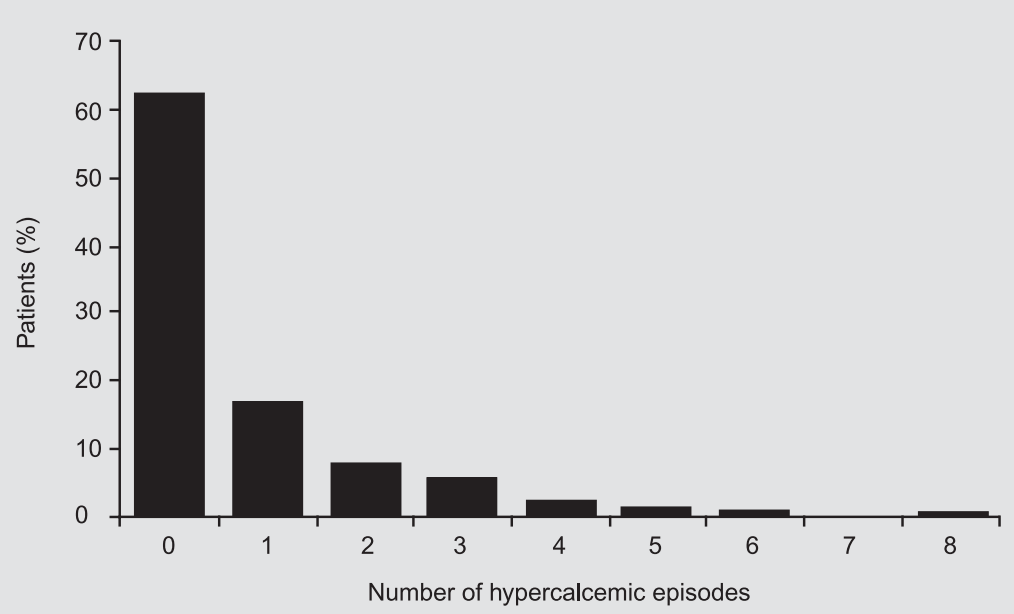

per billion. In those patients who continued lanthanum carbonate treatment, plasma lanthanum levels were not statistically different after 1 year of treatment at doses of $750,1,500,2,250$ or $3,000 \mathrm{mg} /$ day. Figure 5 illustrates that lanthanum levels quickly reached a plateau. Furthermore, plasma lanthanum did not appear to be dosedependent, although there was an apparent statistically significant difference with the $1,500 \mathrm{mg} /$ day dose after the end of the 6-month extension study. As expected, plasma lanthanum levels for all dose groups were higher in the 2-year extension than original baseline levels (week 0).

\section{Discussion}

This study shows that lanthanum carbonate maintains not be excluded. Calcium and phosphate homeostasis in this patient had been under control throughout the study period with lanthanum carbonate and vitamin D therapy.

During the extension studies, no consistent pattern of change was recorded in most laboratory parameters, and no clinically significant changes were seen in measurements of vital signs. There was a slight tendency for alkaline phosphatase and bicarbonate to rise either from low to normal levels or from normal to high levels.

\section{Plasma Lanthanum Levels}

Plasma lanthanum levels during the 6-month extension were very low, representing about $0.33-0.50$ parts efficacy and is well tolerated during treatment for up to 3 years. Hyperphosphatemia is well known to be an independent risk factor for morbidity and mortality in ESRD patients on dialysis [1-4, 27]. Long-term control of serum phosphate in this patient group is therefore vital and may be an important factor in improving patient outcomes.

Pre-clinical and early clinical studies have demonstrated the potential of lanthanum carbonate as a phosphate binder [28, 29]. It is also poorly absorbed compared with aluminium and calcium [28]. Unlike aluminium, which is excreted renally, systemic lanthanum is eliminated primarily by the biliary route $[21,30]$, thereby minimizing the risk of toxicity in patients with renal disease. Previous placebo-controlled trials have indicated that 


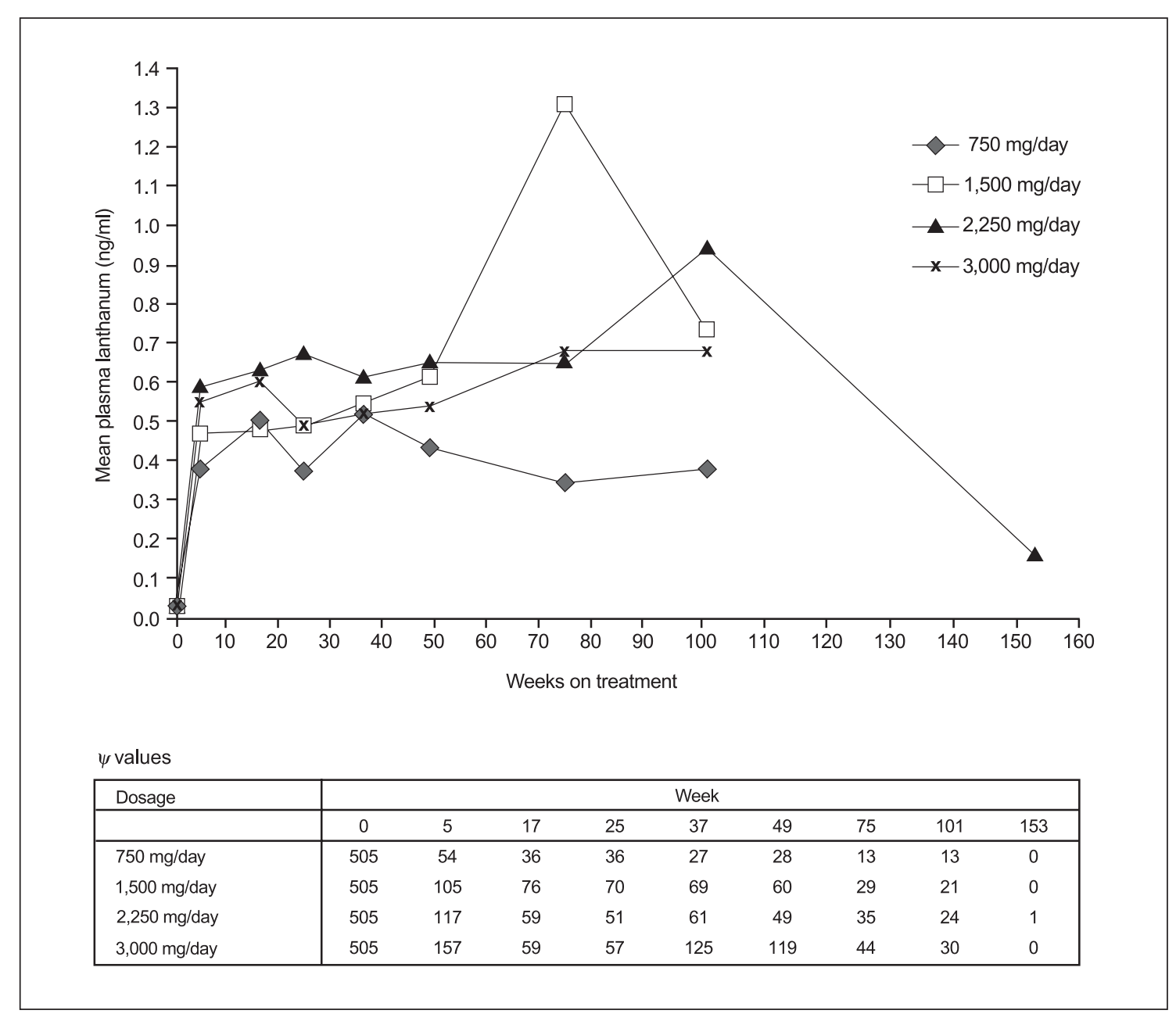

Fig. 5. Mean lanthanum levels in patients who received lanthanum carbonate treatment during the comparatorcontrolled phase and the extension phases.

lanthanum carbonate is effective at reducing serum phosphate to target levels of $\leq 1.8 \mathrm{mmol} / \mathrm{l}(\leq 5.6 \mathrm{mg} / \mathrm{dl})[31$, 32] or $\leq 1.9 \mathrm{mmol} / 1(\leq 5.9 \mathrm{mg} / \mathrm{dl})$ and maintaining it at this level [33]. Furthermore, the comparator-controlled phase of this extension study demonstrated that lanthanum carbonate has similar efficacy to calcium carbonate in controlling serum phosphate at a target level of $\leq 1.8 \mathrm{mmol} / 1(\leq 5.6 \mathrm{mg} / \mathrm{dl})$ over 6 months. In the present extension studies, serum phosphate levels were maintained at levels similar to those observed in the earlier comparative phase. Notably, a subgroup of 46 patients (identified as the long-term-exposure group) demonstrated sustained efficacy for 3 years of lanthanum carbonate treatment, having achieved control of serum phosphate in the earlier phases of the trial and then maintained control throughout this extension. When considering serum phosphate control, it is important to note that dialysis dose, session duration, membrane type and dialytic modality can also play a role; these parameters were not recorded during this study.

The higher serum phosphate levels at the beginning of the 2-year extension study are probably a result of the high number of patients who had a gap in lanthanum carbonate treatment between the two extension phases $(71 \%$ of patients had a gap of more than 2 months), which would have led to a rise in their serum phosphate levels. The proportion of patients who were defined as being controlled by the criteria used in the earlier phases (serum phosphate $\leq 1.8 \mathrm{mmol} / 1[\leq 5.6 \mathrm{mg} / \mathrm{dl}]$ ) was slightly lower in the 2-year extension study than in the previous phases, as there was no target for serum phosphate; investigators were therefore not treating to a goal, but rather monitor- 
ing long-term safety and tolerability. The gradual increase in serum phosphate during the third year of treatment may also reflect the fact that investigators are likely to have maintained patients on a particular dose if only small increases in serum phosphate were observed.

In addition to controlling serum phosphate, it is important to control serum calcium and maintain low $\mathrm{Ca} \times$ $P$ levels, as both of these parameters have been independently associated with calcification risk [1-3]. Throughout these extension studies, patients' serum calcium levels were maintained within values considered to represent a normal range and, importantly, few patients experienced hypercalcemic episodes. The marginally elevated calcium level observed at the beginning of the 2-year study is due to the fact that patients were able to receive calcium-based phosphate binders in the interim period between the extension studies. The proportion of patients experiencing hypercalcemic events decreased throughout the 2-year extension, probably because the effect of the previously received calcium-based binders diminished over time. It may also be due, in part, to patients who experienced hypercalcemia withdrawing from the study, although hypercalcemia was not shown to be a major reason for study withdrawal. It should be noted that investigators were free to alter the dialysate calcium concentration during the study; these data were not collected under the study protocol. $\mathrm{Ca} \times \mathrm{P}$ values were also maintained at a low level throughout treatment and, furthermore, mean values in the 2-year extension did not exceed the value recommended by the 2003 Kidney Diseases Outcomes Quality Initiative (K/DOQI) guidelines [13] $\left(4.4 \mathrm{mmol}^{2} / \mathrm{l}^{2}\left[55 \mathrm{mg}^{2} / \mathrm{dl}^{2}\right]\right)$, even though the trial was conducted before their publication.

Controlling PTH levels is important in the maintenance of normal bone turnover: high PTH levels can lead to high-turnover bone disease, whereas oversuppression of PTH can lead to adynamic bone, as is known to occur with calcium-based phosphate binders [34]. In the current studies, PTH levels showed little change in a large proportion of patients, although there was a slight tendency for levels to rise. In clinical practice, it is anticipated that vitamin $\mathrm{D}$ analogs will be used to effectively suppress PTH. Thus, unlike calcium-based binders, independent control of phosphate, calcium and PTH seems to be possible with lanthanum carbonate.

The incidence and type of adverse events reported in this study were similar to those reported in the comparator-controlled phase of the trial, providing assurance that the tolerability seen over the short term with lanthanum carbonate is maintained over a longer duration. In these extension studies, few adverse events were considered to be drug-related and, given that the majority were classified as mild-to-moderate in severity, few adverse events led to patient withdrawal from the studies. Importantly, there was no evidence of an increase in the frequency of adverse events previously associated with traditional phosphatebinder treatment, such as hypercalcemia, microcytic anemia, fractures or bone pain. The fact that 46 patients (the long-term-exposure group) were able to continue receiving lanthanum carbonate with no increase in the annual incidence of adverse events indicates a favorable safety profile for lanthanum carbonate treatment, with no unexpected adverse events anticipated in the long term.

There was a higher incidence of serious adverse events in the 2-year extension than in the initial 6-month extension and the previous comparator-controlled phase of the trial, as would be expected from the longer study duration. Of the 14 deaths that occurred during this phase, none were considered to be related to lanthanum carbonate treatment. The mortality rate $(8.7 \%)$ was no higher than would be expected in a dialysis population over a 2-year period. Studies by Berthoux et al. [35] and van Dijk et al. [36] suggest 1- and 2-year mortality rates for dialysis patients of $14.4 \%$ and $33 \%$, respectively; these rates are consistent with UK and US registry data.

A limitation of the current study is the relatively small number of patients who completed full follow-up, a common problem of long-term studies in dialysis patients. Although 161 patients entered the 2-year extension, only 46 patients remained at 3 years. Further long-term studies of lanthanum carbonate and other phosphate binders with greater patient numbers would be of value. To our knowledge, the only other prospective study that has investigated treatment with a phosphate binder for a period of up to 3 years was also uncontrolled and conducted with calcium carbonate by Sperschneider et al. [37]. Only 13 patients completed a full 3 years of follow-up. The efficacy of calcium carbonate appeared to deteriorate over 3 years and the extent of calcification increased, with the authors concluding that calcium carbonate alone is not suitable for long-term phosphate reduction in dialysis patients.

In conclusion, we have shown for the first time that the new phosphate binder, lanthanum carbonate, is able to maintain efficacy and is well tolerated for up to 3 years.

\section{Acknowledgement}

This work was supported by Shire Pharmaceutical Development, Inc. 


\section{References}

1 Block GA, Hulbert-Shearon TE, Levin NW, Port FK: Association of serum phosphate and calcium x phosphate product with mortality risk in chronic haemodialysis patients: a national study. Am J Kidney Dis 1998;31:607617.

2 Goodman WG, Goldin J, Kuizon BD, Yoon C, Gales B, Sider D, Wang Y, Chung J, Emerick A, Greaser L, Elashoff RM, Salusky IB: Coronary-artery calcification in young adults with end-stage renal disease who are undergoing dialysis. N Engl J Med 2000;342:1478-1483.

3 Drüeke TB: A clinical approach to the uraemic patient with extraskeletal calcifications. Nephrol Dial Transplant 1996;11(suppl 3):3742.

4 Locatelli F, Cannata-Andia JB, Drüeke TB, Horl WH, Fouque D, Heimburger O, Ritz E: Management of disturbances of calcium and phosphate metabolism in chronic renal insufficiency, with emphasis on the control of hyperphosphataemia. Nephrol Dial Transplant 2002; 17:723-731.

5 Jono S, McKee MD, Murry CE, Shioi A, Nishizawa Y, Mori K, Morii H, Giachelli CM: Phosphate regulation of vascular smooth muscle cell calcification. Circ Res 2000;87: E10-E17.

6 Salgueira M, Del Toro N, Moreno-Alba R, Jiménez E, Arresté N, Palma A: Vascular calcification in the uremic patient: a cardiovascular risk. Kidney Int 2003;63(suppl 85):S119S121.

7 Braun J, Oldendorf M, Moshage W, Heidler R, Zeitler E, Luft FC: Electron beam computed tomography in the evaluation of cardiac calcification in chronic dialysis patients. Am J Kidney Dis 1996;27:394-401.

8 Foley RN, Parfrey PS, Sarnak MJ: Clinical epidemiology of cardiovascular disease in chronic renal disease. Am J Kidney Dis 1998;32(suppl 3):S112-S119.

9 Wang AY, Wang M, Woo J, Lam CW, Li PK, Lui SF, Sanderson JE: Cardiac valve calcification as an important predictor for all-cause mortality and cardiovascular mortality in longterm peritoneal dialysis patients: a prospective study. J Am Soc Nephrol 2003;14:159-168.

10 Goldsmith DJ, Covic A, Sambrook PA, Ackrill P: Vascular calcification in long-term haemodialysis patients in a single unit: a retrospective analysis. Nephron 1997;77:37-43.

11 Wills MR, Savory J: Aluminium poisoning: dialysis encephalopathy, osteomalacia, and anaemia. Lancet 1983;ii:29-34.

12 Malluche HH, Monier-Faugere MC: Hyperphosphataemia: pharmacologic intervention yesterday, today and tomorrow. Clin Nephrol 2000;54:309-317.

13 Eknoyan G, Levin A, Levin NW: K/DOQI clinical practice guidelines for bone metabolism and disease in chronic kidney disease. Am J Kidney Dis 2003;42:1-201.

14 Chertow GM, Burke SK, Raggi P: Sevelamer attenuates the progression of coronary and aor- tic calcification in haemodialysis patients. Kidney Int 2002;62:245-252.

15 Bleyer AJ, Burke SK, Dillon M, et al: A comparison of the calcium-free phosphate binder sevelamer hydrochloride with calcium acetate in the treatment of hyperphosphataemia in haemodialysis patients. Am J Kidney Dis 1999;33:694-701.

16 Qunibi WY, Hootkins RE, McDowell LL, Meyer MS, Simon M, Garza RO, Pelham RW, Cleveland MB, Muenz LR, He DY, Nolan CR: Treatment of hyperphosphataemia in haemodialysis patients: The Calcium Acetate Renagel Evaluation (CARE Study). Kidney Int 2004; 65:1914-1926.

17 Damment SJP, Totten W: The pharmacology of a new phosphate binder, lanthanum carbonate. Poster World Congress of Nephrology Clinical Meeting, Berlin, 2003.

18 Damment SJP, Webster I, Shen V: Bone mineralization defect with high doses of phosphate binders in uraemic rats - an artefact of phosphate depletion? Nephrol Dial Transplant 2002;17(suppl 1):67.

19 Behets GJ, Dams G, Vercauteren SR, Damment SJ, Bouillon R, De Broe ME, D'Haese PC: Does the phosphate binder lanthanum carbonate affect bone in rats with chronic renal failure? J Am Soc Nephrol 2004; 15:22192228.

20 D'Haese PC, Spasovski GB, Sikole A, Hutchison A, Freemont TJ, Sulkova S, Swanepoel C, Pejanovic S, Djukanovic L, Balducci A, Coen G, Sulowicz W, Ferreira A, Torres A, Curic S, Popovic M, Dimkovic N, De Broe ME: A multicenter study on the effects of lanthanum carbonate (Fosrenol) and calcium carbonate on renal bone disease in dialysis patients. Kidney Int 2003;63(suppl 85):S73-S78.

21 Pennick M, Damment SJP, Gill M: The pharmacokinetics and tissue distribution of lanthanum carbonate $\left(\right.$ Fosrenol $\left.{ }^{\circledR}\right)$, a novel nonaluminium, non-calcium phosphate binder. Poster 36th Annual Meeting of the American Society of Nephrology, San Diego, 2003.

22 Damment S, Greaves P, Downes N: The toxicology of lanthanum carbonate $\left(\right.$ Fosrenol ${ }^{\circledR}$ ), a novel non-aluminium, non-calcium phosphate binder. Poster 36th Annual Meeting of the American Society of Nephrology, San Diego, 2003.

23 Lacour B, Lucas A, Auchere D, Ruellan N, de Serre Patey NM, Drueke TB: Chronic renal failure is associated with increased tissue deposition of lanthanum after 28-day oral administration. Kidney Int 2005; 67:1062-1069.

24 McLeod C, Cox A, Bramall N: The need for contamination control in studies on lanthanum disposition. Kidney Int 2005; in press.

25 Hutchison AJ, Maes B, Vanwalleghem J, Asmus G, Mohamed E, Schmeider R, Backs W, Jamar R, Vosskühler A: Efficacy, tolerability, and safety of lanthanum carbonate in hyperphosphataemia: a 6-month, randomized, comparative trial versus calcium carbonate.
Nephron Clin Pract 2005;100:c8-c19. Epub 2005; Apr 4.

26 US Renal Data System (USRDS): Annual Data Report: Atlas of End-Stage Renal Disease in the United States. Bethesda, National Institutes of Health, National Institute of Diabetes and Digestive and Kidney Diseases, 2002.

27 Marco MP, Craver L, Betriu A, Belart M, Fibla J, Fernández E: Higher impact of mineral metabolism on cardiovascular mortality in a European haemodialysis population. Kidney Int 2003;63(suppl 85):S111-S114.

28 Locatelli F, D’Amico M, Pontoriero G: Lanthanum carbonate. IDrugs 2003;6:688-695.

29 Dewberry K, Fox JS, Curtis CG, Murray JR, Hutchison AJ: Lanthanum carbonate is an effective inhibitor of phosphate absorption from the intestinal tract. Nephrol Dial Transplant 1997;12:A98.

30 Evans $\mathrm{CH}$ : Biochemistry of the lanthanides. New York, NY, Plenum Press, 1990.

31 Finn WF, Joy MS, Hladik GA, Lanthanum Study Group: Efficacy and safety of lanthanum carbonate for reduction of serum phosphate in patients with chronic renal failure receiving haemodialysis. Clin Nephrol 2004;62:193201.

32 Yang WC, Chaing SS, Chen JB: Efficacy and safety of lanthanum carbonate in the treatment of hyperphosphataemia in Chinese chronic renal failure patients. Poster 36th Annual Meeting of the American Society of Nephrology, San Diego, 2003.

33 Joy MS, Finn WF: Randomized, double-blind, placebo-controlled, dose-titration, Phase III study assessing the efficacy and tolerability of lanthanum carbonate: a new phosphate binder for the treatment of hyperphosphataemia. Am J Kidney Dis 2003;42:96-107.

34 Martin KJ, Gonzalez EA: Strategies to minimize bone disease in renal failure. Am J Kidney Dis 2001;38:1430-1436.

35 Berthoux F, Jones E, Gellert R, Mendel S, Saker L, Briggs D: Epidemiological data of treated end-stage renal failure in the European Union (EU) during the year 1995: report of the European Renal Association Registry and the National Registries. Nephrol Dial Transplant 1999; 14:2332-2342.

36 van Dijk PC, Jager KJ, de Charro F, Collart F, Cornet R, Dekker FW, Gronhagen-Riska C, Kramar R, Leivestad T, Simpson K, Briggs JD: Renal replacement therapy in Europe: the results of a collaborative effort by the ERAEDTA registry and six national or regional registries. Nephrol Dial Transplant 2001;16: 1120-1129.

37 Sperschneider H, Gunther K, Marzoll I, Kirchner E, Stein $\mathrm{G}$ : Calcium carbonate $\left(\mathrm{CaCO}_{3}\right)$ : an efficient and safe phosphate binder in haemodialysis patients? A 3-year study. Nephrol Dial Transplant 1993;8:530-534. 